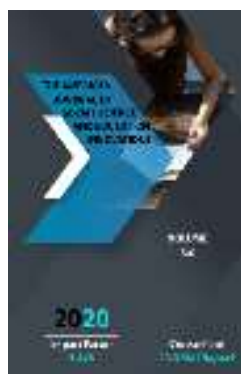

\title{
Models Of State Sports Policy (Content Analysis)
}

Olim Neymatovich Akhmedov

Teacher Of The Department Of Social Sciences, Uzbek State University Of World Languages, Uzbekistan

Journal Website:

http://usajournalshub.c om/index,php/tajssei

Copyright: Original content from this work may be used under the terms of the creative commons attributes 4.0 licence.

\section{ABSTRACT}

In order to determine the limits of state intervention in the field of physical culture and sports, it is necessary to study the model of the relationship between the state and sports. This article also examines interventionist, non-interventionist, and mixed models in the implementation of public sports policy. It also analyzes the problems of state and non-state sports, the fact that despite the parallel existence of state and non-state sports, regardless of the sources and nature of funding, they are the object of public policy.

\section{KEYWORDS}

Sports, physical education, public policy, physical education and sports policy, public sports, nongovernmental sports, model.

\section{INTRODUCTION}

It is known that one of the priorities of the state is to meet the needs of the population, including socio-cultural and economic-social support, as well as a healthy lifestyle, physical culture and sports. This does not mean that economic relations in sports are the only object of public policy. Through sports, the state pursues a policy aimed not only at economic indicators, but also at the health of the nation, the development of national ideology, social assistance, education, public order, and so on.

The Law "On Physical Culture and Sports" [1], adopted on July 24, 2015, "On measures to further improve and popularize physical culture and sports in the Republic of Uzbekistan" 2020 Decree No. PF-5924 of 
January 24, 2011 and its Annex 1 set out in the Concept of Development of Physical Culture and Sports in the Republic of Uzbekistan until 2025 [2]. They define the goals, objectives and main directions of long-term development of state policy in the field of physical culture and sports in the country, the basics of legal, organizational, economic and social activities and the basic principles of physical culture and sports legislation.

Usually the system of social relations governed by the state is understood as the object of public policy. In the political sciences, the approach of physical education and sports as an object of state policy is quite controversial. There is no doubt that the state's participation in this sphere of social life is growing today. What is the positive impact of the state policy on sports? Since when has sport become an object of state policy? In our opinion, without answering these questions, it is impossible to fully understand the essence of state policy in the field of physical culture and sports. Below we attempt to analyze some of the approaches available in the political sciences on this issue.

\section{THE MAIN PART}

In recent years, the number of views on the nature and content of sports in the scientific literature has increased. One of the main reasons for this is the rapid development of sports in the commercial direction. According to the Russian researcher A.A. Isaev, "athletes in their sports activities focus mainly on financial incentives, material wealth, popularity." [3].

At the same time, the sport as a whole object has not lost its characteristic features. According to the Russian scientist VM Vydrin, sport is a game activity aimed at revealing the ability of a person to move in a competitive environment [4]. Another Russian researcher, B.A. Lysitsyn, points out that sport has a certain independence in the eyes of the public. The final and clear result of the preparation for the competition, the only criterion for the level of training of the athlete, the result of which is the criterion of public recognition [5].

By the way, the goal of the athlete is to achieve a good result by performing a certain exercise. This result is evaluated by specialists with special qualifications on the basis of certain rules and is publicly recognized. However, today sport should be expressed not only in the form of sports competitions, but also as a social phenomenon, a part of culture, an important aspect of social relations or economic activity. Finally, sport should be represented as an object of public policy.

In order to gain a deeper understanding of the state policy on the development of physical culture and sports, it is expedient to analyze the existing legal framework in the field of physical culture and sports. After all, the state policy in the field of sports is mainly reflected in the legislation. The most important legal act in this area today is the Law "On Physical Culture and Sports", adopted on July 24, 2015. This normative document represents sports as a field of socio-cultural relations, ie a set of sports formed as sports competitions.

The competitive component of sport is important, but there are other approaches to representing sport as an object of state regulation. As a form of sports play activity, it focuses on a person's physical development compared to other people's achievements and opportunities [6].

But the emphasis on sports as just a game is a bit outdated. In team sports, sport can be emphasized as a game, but here the game 
remains only a form of competition and does not reflect all the other characteristics of a particular sport. In this regard, in the scientific literature, sports are represented as a concept of an object regulated by the state, due to the influence of the multifaceted relationships formed between the participants of sports competitions. Sport is a complex phenomenon, consisting of social-labor, civillegal, administrative and other relations that are formed between different subjects.

In sports, in order to determine the limits of state participation in physical culture and sports, it is necessary to study the relationship between them, which is in the process of formation. There are various models of state policy on sports in the scientific literature.

One of the manifestations of state policy is its policy in the field of physical culture and sports. This policy is based on the principle of full subordination of the industry to the state or non-interference of the state in the field of physical culture and sports at all. In this regard, the communication between the state and sports takes the form of three models interventionist, non-interventionist and mixed model.

According to the interventional model, the forms and basic rules of management of the subjects of the sports system are determined by the state. In forming this relationship, the state will create a solid legal framework for sports activities, provide extensive funding for sports activities, control the behavior of participants in sports events, ensure security, support sports infrastructure, address all organizational issues will remain its main task.

On the contrary, according to the noninterventionist model, sport is recognized by the state as an autonomous (independent) system of self-government. A sport with full independence is not supported by the state and is not accountable to it. Entities engaged in sports activities do not have the rights, guarantees, obligations and privileges established by the state. Of course, it is difficult to imagine the relationship between the state and sports entities in modern political systems, but proponents of this non-interventionist model cite the UK as an example of sports being run by non-governmental institutions [7]. In this case, the subjects engaged in sports activities are subject only to their own norms, and control over their observance is entrusted to sports organizations or specially formed public control bodies. In particular, this model of state non-interference in the activities of sports entities is officially recognized in the international sports system as an absolute nonpolitical social institution.

But is it possible to imagine modern sports separately from state policy? Of course, today's sport cannot be imagined without the participation of the state. Sport as a social institution remains under the influence of a number of events taking place in society, including political processes. This is reflected in the nature of the relationship that is being formed between the state and society. It is difficult to imagine the organizational (issues) component of modern sports without state support. It is impossible to imagine a complete sports system without sufficient material and technical base, protection of the rights of participants in sports competitions and social guarantees by the state. And finally, it is unthinkable that public sporting events, including international competitions, can be held by law enforcement agencies without ensuring security and public order. 
In view of the above, some proponents of the non-interventionist model have concluded that it is utopian in nature, with most modern countries participating in some form of physical education and sports management. The state's participation in sports is wellfounded, because "sports activity is a social, public activity, which involves a number of subjects, so it is known among them, in particular, among athletes, their employers (sports clubs, physical culture and sports organizations) and society. it is important to maintain a balance, a balance "[8]. Countries that have more prizes in international sports competitions will gain prestige and respect in the international arena.

Thus, the third-view relationship between state and sport can be conditionally called a mixed model. Based on which segments of public administration affect the sports system, this model identifies a number of options for public participation in sports. In this regard, three main emblems of the mixed model can be seen:

1) Equality of state and sport based on the interrelated aspects predetermined and articulated within the framework of the powers of public authorities and selfgoverning public sports organizations. The resolution of disputes between them will be pre-determined. The founder of this version of the mixed model is John Barnes (University of Western Ontario). According to him, the state is responsible for security issues in the conduct of sporting events, the legal regulation of the definition and implementation of the rights of participants in sports competitions, fundamental aspects of entrepreneurial activity in sports, including taxation [9]. Participants in sports activities will have the opportunity to agree with the state on this issue and demand that the state regulate these relations in a proper manner.

2) Participants in sports activities have social obligations to the state [10]. Like other entities engaged in certain activities in the territory of the state, representatives of physical culture and sports are obliged to comply with existing legislation, are responsible for compliance with the legal requirements of the state and various violations. The state may delegate some of its powers to sports entities (for example, in defining and maintaining sports discipline), but cannot completely remove the system of physical culture and sports from its jurisdiction due to the obligation to ensure the rights and interests of all citizens and organizations involved in sports. . According to this model, the state is entrusted with its main task, the function of an independent institution of control that protects the public interest.

3) the state has an obligation to support the sport, however, as matters of reciprocity are resolved when necessary, not predefined and defined by law. In this case, the state can develop various strategies and programs in the framework of large-scale sporting events or the implementation of social reforms and predict a tentative list of these issues. In our opinion, this model has been established in the Republic of Uzbekistan for the last decade.

But there are other views in the scientific literature that express the relationship between sports and the state. In some of these views, sports are conditionally divided into two parallel state and non-state systems [11]. The interest of the state in supporting a particular 
sport determines that the main criterion for this classification. Undoubtedly, the state clearly demonstrates its interest in a particular sport. On the contrary, non-state sports are absolutely autonomously parallel to public policy, as a result of which it forms its own unique system of governance.

According to Yu.A.Voronin, from this point of view it is important to include mass and commercial sports in non-governmental sports [12]. The goal of mass sports is health, the goal of commercial sports is profit, and the goal of state sports is sports records and "country reputation". TS Khusnitdinov distinguishes between mass, commercial, professional and semi-professional sports [13]. According to another scholar, TV Nizyaeva, sources of funding are one of the important criteria for the division of sports into public and private, and the state's confidence in a particular sport or event [14]. However, from a financial point of view, sports can be divided not only into state and non-state sports, but also state sports with private investment, public sports with public and international financial institutions, and non-state sports formed by the state on the basis of various forms of financial support. Given the different forms of sponsorship in sports, it is wrong to divide it into only state and non-state types.

\section{CONCLUSION}

Despite the parallel existence of state and nonstate sports, regardless of the sources and nature of funding, they remain the object of public policy. It is known that physical culture and sports do not develop only through state mechanisms. Today, competitions are being held in new sports, and technical and technological innovations are being introduced in certain sports. Due to its investment attractiveness, attention and interest of the population, international experience, the field of sports activities, which in the past was not given enough attention, today is becoming an object of state sports policy.

\section{REFERENCES}

1. Uzbekistan RespuBlikasining "Zismonij training and sport ty̆ørisida" KI Law. Jil 24 July 2015. (See: Law of the Republic of Uzbekistan "On Physical Culture and Sports." July 24, 2015.)

2. Uzbekistan Prezidentining 2020 jil 24 janvardagi "Uzbekistan RespuBlikasida zismonij training and sportni janada takomillaştiriş and ommalaştiriş tadBirlari ty̆orisida" KI IM-5924-might command. (Decree of the President of the Republic of Uzbekistan dated January 24, 2020 No PF5924 "On measures to further improve and popularize physical culture and sports in the Republic of Uzbekistan.")

3. Isaev AA Sportivnaja Rossii. Suhrob-M .: Sovetskij sport, 2002. -S.54. (Isaev A.A. Sportivnaya politika Rossii. -M .: Sovetskiy sport, 2002.-P.54.)

4. Vыdrin .and Vvedenie speцialbnostb: Uceв. Printable posobie institutov fiziceskoj kulbturb.-M., 1980. S.12. (See Vydrin V.M. Introduction to specialization: Ucheb. Posobie dlya institutov fizicheskoy kultury.-M., 1980.-S.12.)

5. Lisiцыn B.A. K voprosu ponjatii "sport" .// Teorija praktika fiziceskoj kulbturb. 1974. №2. S.62. (See Lisitsyn B.A. K voprosu o ponyatii "sport" .// Theory and practice of physical culture.-1974.-№2.-S.62.)

6. Vыdrin .and Vvedenie speцialınostb: Uceв. Printable posobie institutov fiziceskoj kulbturb.-M., 1980. S.12. (Vydrin V.M. 
Introduction to specialization: Ucheb. Posobie dlya institutov fizicheskoy kultury.-M., 1980.-S.12.)

7. Pogosjan E.V.Formb razreșenija sportivndx sporov: monographs. -M. Volbters: Kluver, 2011.-160s. (Pogosyan E.V.Formy razresheniya sportivnyx sporov: monograph. -M .: Volters Kluver, 2011.16op.)

8. Felops U., Morali A. Sell, J. et al., E. Mikhailov, Gorцunjan S., A. Kljacin, Sport object More pravovogo regulirovanija VelikoBritanii // Sport: ekonomika, pravo, upravlenie.-2006.-3. -S.9-16. (Felops U., Morali A., Sell Dj., Mikhailov E., Gortsunyan S., Klyachin A., Sport as an object of legal regulation in Great Britain // Sport: economics, law, management.-2006.-№ 3. -S.9-16.)

9. Barnes J. Sports and the law in Canada, Toronto.-Butterworth, 1996, -261. (Barnes J. Sports and the law in Canada, Toronto.Butterworth, 1996, -261).

10. McLauren R.A. New Order: Athletes Rights and the Court of Arbitration at the Olympic games // Olimpica: The International Journal of Olympic Studies.-1998.-Vol. VII.P.26-35. (McLauren R.A. New Order: Athletes Rights and the Court of Arbitration at the Olympic games // Olimpica: The International Journal of Olympic Studies.-1998.-Vol. VII.-P.26-35.)

11. Ivanov I.S. Castno-NA sport [Electron source] // Gazeta.ru.-2007.-3-maja. URL: http:

//www.gazeta.ru/commehts/2007/05/03_a _1649455.shtml (Date oвraщenija: 01.07.2012 ). (Ivanov IS Castno-NA sport [Electronic source] // Gazeta.ru.-2007.-3 May.-URL: http: //www.gazeta.ru/commehts/2007/05/03_a

\section{_1649455.shtml (data obrashcheniya: 01.07.2012).}

12. Voronin Ju.A. Olimpijskoe naduvatelbstvo // Literaturnaja gazeta. 2002. №11. S.6-7. (Voronin Yu.A. Olimpiyskoe naduvatelstvo // Literaturnaya gazeta.-2002.-№11.-S.6-7.)

13. Xusnitdinov Maybe Tajikistan News sport Massovыj Rossijskoj object More soцialınogo regulirovanija: primere vzaimodejstvija organov NA upravlenija овщеstvennыx organizaцij sportivnoj napravlennosti: Dissertations. kand.soц.nauk. -Kazanb, 2004 -24. (See Khusnitdinov K.S. Mass sports in the Russian Federation as an object of social regulation: on the first interaction of state bodies of public administration and general sports organizations: Abstract. Kand.sots.nauk. -Kazan, 2004. -24.)

14. Nizjaeva T.V. Finansirovanie fiziceskoj, 1999 kulbturb sporta: Dissertations kand.ekonom.nauk.. M. -22. (Nizyaeva T.V. Finansirovanie fizicheskoy kultury i sporta: Avtoreferat kand.ekonom.nauk.-M., 1999.$22 \mathrm{s.})$ 